\title{
Evo-lución: The Economic Situation of Evo Morales' Bolivia under Scrutiny
}

Christian Dalenz

Freelance Journalist

\begin{abstract}
This paper deals with economic changes in the last 12 years in Bolivia under the presidency of Evo Morales. After a short introduction about the political landscape of the country, I will explain how Morales' party, Movimiento al Socialismo, planned to change Bolivia's economic model. Here I will rely on the works by former Bolivian Ministry of Economics and Public Finances, Luis Arce Catacora. Then I will show the improvements in social conditions of the Bolivian population during the Morales' presidency, and I will relate them to the Cash Conditional Transfers adopted by the government, otherwise known as bonos. Finally, I will assess the intricate issue of economic and environmental sustainability of this model. My point of view is that since Bolivia will soon face less revenue from its gas exports, efforts in diversifying its economy will have to improve. At the same time, no major crisis should happen.
\end{abstract}

\section{Keywords}

bonos, Developmental State, economic model, hydrocarbons, inequality, neoliberalism, oil, poverty 


\section{Resumen}

Este estudio está enfocado en los cambios económicos sucedidos en los últimos 11 años en Bolivia, bajo la presidencia de Evo Morales. Luego de una breve introducción al panorama político del país, explicaré cómo el partido de Morales, el Movimiento al Socialismo (MAS), planificó el cambio de modelo económico de Bolivia; para esta tarea, voy a utilizar como fuentes los trabajos del anterior Ministro de Economía y Finanzas Públicas de Bolivia, Luis Arce Catacora. A continuación, mostraré el mejoramiento de las condiciones sociales de la población boliviana en el periodo de la presidencia de Morales, y las pondré en relación con las Transferencias Condicionadas adoptadas por el gobierno, conocidas también como bonos. Finalmente, enfrentaré el delicado problema de la sostenibilidad económica y ambiental de este modelo. Mi punto de vista es que, como Bolivia tendrá menos ingresos por sus exportaciones de gas, los esfuerzos hacia la diversificación de su economía tendrán que mejorar. Al mismo tiempo, no debería llegar una crisis demasiado fuerte.

\section{Palabras claves}

bonos, desigualdad, Estado desarrollista, hidrocarburos, modelo económico, neoliberalismo, petróleo, pobreza

\section{Introduction}

The Movimiento al Socialismo (MAS) won the Bolivian elections in 2005 with $56 \%$ of the votes and its leader, Juan Evo Morales Ayma, became President. For the first time in its democratic era the nation had a president chosen by ballot (previously, presidents were always chosen by the Parliament because no party or coalition alone ever won an absolute majority of votes) and it was the first time that an indigenous person conquered the Palacio Quemado

This event was acclaimed worldwide and some thought that a Morales government would have been very radical. In reality, the truth was that MAS proposals were moderate relative to those advanced by other left-indigenous parties (Webber 2011a), allowing it to conquer even middle-class favor. At the same time, there has been an effort to coordinate governmental political action together with social movements through what is reminiscent of the 
Pacto de Unidad (Unity Pact). Álvaro García Linera (2011), Bolivia's VicePresident considers the MAS government as the "the government of the social movements." 1

Morales proclaimed that he was going to promote deep and structural changes in his country. As Artaraz and Calestani (2015) have underlined, an indigenous principle: the Suma Qamaña, Well-Being in Aymara (a local language) was chosen as the basis of policy. This concept tries to overtake the neoliberal dogma of self-responsibility (McNay 2009) as the only key for wellbeing and it comprises a collective dimension and a holistic approach in which the goal is to arrive at a balance between people and nature. This implies a stronger role for indigenous rights and respect for their forms of living, considered a source of inspiration for policy. The idea is to go beyond the neoliberal ideology expressed in the Washington Consensus (Williamson 1990) that the country followed in the ' 80 s and the 90 's

Whether such spiritual claims can be materialized is another story. For the time being, we know that poverty conditions, especially for some indigenous groups, have improved significantly. Nevertheless, as we shall see, despite massive efforts by the State to industrializethe country, there are doubts about the sustainability of the actual economic model, both in economic and environmental terms. The country is still very dependent on gas exports and the decline of the international commodity boom has caused a deceleration in growth. Severe doubts also have been cast about the coherence of the government in protecting Bolivian natural heritage.

At the same time, no major economic crisis should occur in the medium run. Oil prices (crucial for Bolivia, as we will see) will rise again according to predictions; still, not to the levels that sustained high growth in the country in the last decade. Hopes rest on the ability of the State to foster both public and private initiative.

\section{MAS Socioeconomic Plan for Bolivia}

In the National Development Plan 2006-2011 (Gaceta Oficial de Bolivia 2007), we can appreciate how the new economic model is shaped. There is a

\footnotetext{
${ }^{1}$ Webber (2017) accounts that relations between the Bolivian government and some of these social movements deteriorated through the years.
} 
main axis of strategic industrial sectors in which the State would have a leading role and a second axis of public firms, to be used to foster private initiative. The first axis includes hydrocarbons, mining, electric power and environmental sources, while the second one involves agriculture, manufacturing, handicraft production, tourism and housing. Between the first two axes, there is a transversal one which consist in infrastructures and support to production. The idea is to transfer the surplus produced in the first axis towards the sectors of the second axis with the help of the third one, in order to industrialize the country and go beyond an export model based mainly on trading raw materials and fostering domestic demand (Arce Catacora 2016).

FIRST AXIS: Public firms generating surplus

\begin{tabular}{|l|l|l|}
\hline YPFB (hydrocarbons) & $\begin{array}{l}\text { COMIBOL (mining } \\
\text { industry) }\end{array}$ & VINTO (tin) \\
\hline $\begin{array}{l}\text { MI TELEFÉRICO (La } \\
\text { Paz's cableway) }\end{array}$ & ENTEL (communications) & $\begin{array}{l}\text { ENDE } \\
\text { (electricity) }\end{array}$ \\
\hline MUTÚN (steel) & & \\
\hline
\end{tabular}

\section{SECOND AXIS: Public firms generating public and} private employment and surplus

\begin{tabular}{|l|l|l|}
\hline $\begin{array}{l}\text { CARTONBOL } \\
\text { (cardboard) }\end{array}$ & COFADENA (army) & EBA (almonds) \\
\hline EMAPA (food) & LACTEOSBOL (milk) & ABE (outer space) \\
\hline $\begin{array}{l}\text { AZUCARBOL } \\
\text { sugar, located in } \\
\text { Bermejo) }\end{array}$ & $\begin{array}{l}\text { EASBA (sugar, located in } \\
\text { San Buenaventura) }\end{array}$ & $\begin{array}{l}\text { EBIH (hydrocarbons } \\
\text { industrialization) }\end{array}$ \\
\hline ECEBOL (concrete) & PAPELBOL (paper) & EEPS (seeds) \\
\hline EEPAF (fertilizers) & PROMIEL (honey) & \\
\hline
\end{tabular}




\section{THIRD AXIS: Infrastructural public firms}

\begin{tabular}{|l|l|l|}
\hline $\begin{array}{l}\text { BOA (airline } \\
\text { company, flag carrier) }\end{array}$ & DAB (customs) & $\begin{array}{l}\text { TAB (cargo airline } \\
\text { company }\end{array}$ \\
\hline $\begin{array}{l}\text { Bolivia TV } \\
\text { (television) }\end{array}$ & $\begin{array}{l}\text { QUIPUS (information } \\
\text { technology) }\end{array}$ & ENABOL (ships) \\
\hline BOLTUR (tourism) & ENAVI (glass) & \\
\hline
\end{tabular}

Table 1: Bolivian Public Firms in the New Economic Model Source: Arce Catacora 2016 (in brackets, the production performed by the industry)

Here we portray the model as it has been built by the Bolivian government and called by García Linera "Andean-Amazonian capitalism" (Stefanoni and Svampa 2007), a first step towards potential socialization of the economy. Bolivian Minister of Economy, Luis Alberto Arce Catacora, calls it the "New Economic, Social, Communitarian and Productive Model" (Arce Catacora 2016) and describes the strategy as one to overcome capitalism in a pragmatic way. ${ }^{2}$

Not all these firms are operating, though, as we shall see.

THE NEOLIBERAL MODEL

Free market. Market is the mechanism by which resources are distributed and disequilibria are corrected. Efficient Market Hypothesis.
THE NEW BOLIVIAN

MODEL

The State intervenes to correct market failures, such as: non-existence of wealth redistribution and transnational monopoly of strategic firms

\footnotetext{
2 García Linera and Arce Catacora arrived at similar conclusions in their analysis and proposals, but from different point of views: while the former has been a politician since his youth and studied mathematics and sociology, the latter is an economist involved in politics in a second stage of his life. Intellectually, they participated in two different groups of study, the Comuna group (García Linera) and the Duende group (Arce Catacora), which eventually joined forces to develop a new political plan for Bolivia (Arce, 2011; Mun, 2015).
} 


\section{Watchman State. Market is the self-regulator mechanism of the economic process}

Active participation of the State in the economy. The State must intervene in the economy through six roles: planner, entrepreneur, regulator, benefactor, promoter, banker

State privatizes its assets, surpluses are
transferred abroad and Bolivian natural
resources are not protected

Nationalization and control of strategic natural resources

Development is fostered through productive industrialization

Redistribution of wealth, plural economy and social inclusion

\begin{tabular}{|ll|}
\hline Economy focused on private initiative & $\begin{array}{l}\text { State as a promoter of } \\
\text { a plural economy, with } \\
\text { public, private and } \\
\text { indigenous communi- } \\
\text { ties involvement }\end{array}$ \\
\hline Growth based on external demand & $\begin{array}{l}\text { Growth based on both } \\
\text { external and internal } \\
\text { demand }\end{array}$ \\
\hline $\begin{array}{l}\text { Dependency on foreign savings for investment; } \\
\text { indebtedness and fiscal deficit }\end{array}$ & $\begin{array}{l}\text { Generation of internal } \\
\text { resources for } \\
\text { investment; less } \\
\text { indebtedness and fiscal } \\
\text { surplus }\end{array}$ \\
\hline $\begin{array}{l}\text { Stagnation, poverty, inequality of wealth and job } \\
\text { opportunities }\end{array}$ & $\begin{array}{l}\text { More development, } \\
\text { wealth redistribution } \\
\text { and employment } \\
\text { generation }\end{array}$ \\
\hline $\begin{array}{l}\text { Macroeconomic stability as an aim for its own } \\
\text { sake }\end{array}$ & $\begin{array}{l}\text { Macroeconomic } \\
\text { stability as a social } \\
\text { patrimony to impulse } \\
\text { economic development }\end{array}$ \\
\hline
\end{tabular}

Table 2: Differences between the Neoliberal Model and the New Bolivian Model Source: Arce Catacora 2016 
On the left, we see the common neoliberal model: preference for private initiative, export-led growth based on comparative advantage and macroeconomic stability, as well as the inequality effects it usually brings (Ostry, Loungani and Furceri 2016). On the right, a sort of post-Keynesian State $^{3}$ is described: very active in generating an economy that has social scope, with the peculiar characteristic of being financed by State exploitation of the immense Bolivian natural resources. The final aim is to achieve both macroeconomic stability and industrialization. In this way, the Bolivian State would obtain fiscal balance, which neoliberals would like, and heavy public spending, which neoliberals wouldn't like at all (Williamson 1990).

\section{What Really Happened?}

In practice, the privatization of public companies by the governments of the 90 's was only partly inverted to make it more profitable to the country. Many foreign multinational companies lost their property in Bolivia and those that entered into new agreements with the country had to pay more royalties to the State. (Arce 2016)

Nevertheless, thanks to the commodities boom (which we will treat later) and negotiation of new contracts, revenues skyrocketed, particularly in the strategic natural gas sector. Royalties owed by private partners rose to $82 \%$ for bigger plants before the contracts were renegotiated, as a sort of a pressure. But this decision turned out to be a weaker change than announced because the tax increase decided by Morales is in reality contingent upon the pace at which transnational companies recuperate costs and past investments as well as the volume of their production (Webber 2011b). So, not being a fixed additional tax and given that a fixed increase of State revenues up to $50 \%$ had been already decided in 2005 (before that the tax rate on foreign companies was only $18 \%$ ), the tax on hydrocarbons has been only slightly changed by Morales. Nevertheless, the contracts negotiated by his government did represent some increase in revenue in respect to the past. (Medinaceli 2012, Webber 2011b)

During the gas boom, Bolivia acquired huge amounts of foreign currency reserves that allowed the country to peg the peso to the dollar and achieve

\footnotetext{
${ }^{3}$ Arce Catacora (2016) probably would reject such a definition, because he denounces the categorization between monetarism and Keynesianism as "intellectual miopy."
} 
exchange rate stability. These revenues also allowed the government to establish a new welfare state with Conditional Cash Transfers such as:

Renta Dignidad that expanded an already existing similar measure (the BONOSOL) benefitting every retired Bolivian over 60 years.

Bono Juancito Pinto given to poor families to send their children to school.

Bono Juana Azurduy that provides medical attention for pregnant and poor mothers. ${ }^{4}$

At the same time, fiscal surpluses were constantly achieved until 2014. Since then, Bolivia is running deficits, probably to face growth deceleration. ${ }^{5}$

Another important part of the MAS plan for Bolivia is the agrarian reform. With Ley № 3545 of Reconducción Comunitaria de la Reforma Agraria (Law № 3545 about Comunitarian Adjustment of the Agrarian Reform) enacted in 2006, the government intended the redistribution of unassigned lands to indigenous groups and required private lands to have a Función Económico Social (FES) (Social and Economic Function) to assure that they perform for the good of the many. The new law is basically an attempt to improve the redistributive efforts of the Agrarian Reform that the country has been developing since the 1952 Revolution. (Klein 2011)

\section{Overview of Bolivia's Socioeconomic Performances under Morales 6}

As we can see from the National Development Plan 2006-2011, the socioeconomic objectives of the MAS were the acceleration of growth and the

\footnotetext{
4 This latter program in particular receives major funding from the Inter AmericanDevelopment Bank (Klein, 2011).

5 Source: IMF database.

${ }^{6}$ The aim of the following Tables is to present, for each figure, the situation that Morales found when he took charge and the last available data. I preferred to rely in particular on relevant international sources when data were available; when this was not possible, I took data from other sources. Therefore, the hierarchy of sources chosen is: World Bank or UNESCO, Economic Commission for Latin America, and Bolivian National Institute for Statistics. If the firsts were not available, I relied on the second one and if this was neither available I relied on the third one.
} 
reduction of unemployment, inequality and poverty. In Tables Group 1, we can appreciate whether or not these objectives were reached.

\begin{tabular}{|l|c|c|}
\hline Average Growth & 1995-2005 & 2006-2016 \\
& $3.4 \%$ & $4.9 \%$ \\
\hline
\end{tabular}

Source: World Bank database

\begin{tabular}{|l|l|l|}
\hline Unemployment & 2005 & 2015 \\
\hline & $5.4 \%$ & $3.1 \%$ \\
\hline
\end{tabular}

Source: World Bank database

\begin{tabular}{|l|l|l|}
\hline GDP per capita (in US\$̦, 2010 prices) & 2005 & 2016 \\
\hline & 1.720 & 2.457 \\
\hline
\end{tabular}

Source: World Bank database

\begin{tabular}{|l|c|c|}
\hline Gini Index & 2005 & 2015 \\
\hline & 58,5 & 45,8 \\
\hline
\end{tabular}

Source: World Bank database

\begin{tabular}{|l|l|l|}
\hline Poverty ratio & 2005 & 2014 \\
& $59.6 \%$ & $38,6 \%$ \\
\hline
\end{tabular}

Source: World Bank database

\begin{tabular}{|l|l|l|}
\hline Poverty ratio, indigenous groups & 2004 & 2013 \\
\hline & $67.2 \%$ & $48.4 \%$ \\
\hline
\end{tabular}

Source: ECLAC database 


\begin{tabular}{|c|c|c|}
\hline Poverty ratio, non-indigenous groups & 2004 & 2011 \\
\hline & $45.3 \%$ & $35.3 \%$ \\
\hline
\end{tabular}

Source: ECLAC database

\section{Tables Group 1: Socioeconomic Accomplishments During MAS Governments}

As we can see from Tables Group 1, all the figures have improved impressively during Morales' governments. Growth has been on average higher than the previous decade; unemployment is inferior to the 2005 figure; GDP per capita is higher; the Gini index for inequality is much lower; general poverty has been reduced by almost a third for the overall population, by almost $20 \%$ among indigenous groups and by $10 \%$ among non-indigenous groups.

\begin{tabular}{|l|l|l|}
\hline Poverty rate, people between 55-64 years old & 2004 & 2013 \\
\hline & $53.8 \%$ & $25.5 \%$ \\
\hline
\end{tabular}

Source: ECLAC database

\begin{tabular}{|l|l|l|}
\hline Poverty rate, people older than 65 years old & 2004 & 2013 \\
\hline & $58.7 \%$ & $32.4 \%$ \\
\hline
\end{tabular}

Source: ECLAC database

\begin{tabular}{l|c|c|}
$\begin{array}{l}\text { Pregnant women receiving prenatal care } \\
\text { (\% of total) }\end{array}$ & 2003 & 2012 \\
\hline & $79 \%$ & $90 \%$ \\
\hline
\end{tabular}

Source: World Bank database

\begin{tabular}{|l|c|l|}
\hline $\begin{array}{l}\text { Births attended by skilled health staff } \\
\text { (\% of total) }\end{array}$ & 2003 & 2012 \\
\hline & $60.8 \%$ & $84.8 \%$ \\
\hline
\end{tabular}

Source: World Bank database 


\begin{tabular}{|l|c|c|}
\hline $\begin{array}{l}\text { Maternal mortality ratio } \\
\text { (per 100.000 live births) }\end{array}$ & 2005 & 2015 \\
\hline & 305 & 206 \\
\hline
\end{tabular}

Source: World Bank database

\begin{tabular}{|l|c|c|}
\hline $\begin{array}{c}\text { Neonatal mortality } \\
\text { (per } 1.000 \text { live births) }\end{array}$ & 2005 & 2016 \\
\hline & 27.1 & 19 \\
\hline
\end{tabular}

Source: World Bank database

\begin{tabular}{|l|c|c|}
\hline Adult literacy rate $(15+)$ & 2001 & 2012 \\
\hline & $86.7 \%$ & $92.4 \%$ \\
\hline
\end{tabular}

Source: World Bank database

\begin{tabular}{|l|c|c|}
\hline $\begin{array}{l}\text { Out-of-school rate, primary } \\
\text { education }\end{array}$ & 2005 & 2015 \\
\hline & $3 \%$ & $10.1 \%$ \\
\hline
\end{tabular}

Source: UNESCO database

\begin{tabular}{|l|c|c|}
\hline $\begin{array}{l}\text { Out-of-school rate, lower } \\
\text { secondary education }\end{array}$ & 2005 & 2015 \\
\hline & $1.6 \%$ & $9.1 \%$ \\
\hline
\end{tabular}

Source: UNESCO database

\begin{tabular}{|l|c|c|}
\hline $\begin{array}{l}\text { Out-of-school rate, upper } \\
\text { secondary education }\end{array}$ & 2005 & 2015 \\
\hline & $16.3 \%$ & $16.7 \%$ \\
\hline
\end{tabular}

Source: UNESCO database

\begin{tabular}{|l|l|l|}
\hline $\begin{array}{l}\text { Dropout rate, primary } \\
\text { education }\end{array}$ & 2005 & 2014 \\
\hline & $22.46 \%$ & $3.52 \%$ \\
\hline
\end{tabular}

Source: UNESCO database 


\begin{tabular}{|l|c|c|}
\hline $\begin{array}{l}\text { Dropout rate, lower } \\
\text { secondary education }\end{array}$ & 2005 & 2014 \\
\hline & $7.76 \%$ & $9.91 \%$ \\
\hline
\end{tabular}

Source: UNESCO database

Tables Group 2: Evaluation of Bonos Effects

Looking at these figures, one would say that while Renta Dignidad and Bono Juana Azurduy brought successful results, the evidence for Bono Juancito Pinto is mixed. In the purple Tables, we can see that poverty among the older population has decreased by almost half, while the blue Tables show that medical care for pregnant mothers has increased and that mortality for both mothers and newborn children has decreased. But the data in the green Tables show mixed results about education. Adult literacy and the out-of-school rates for primary and secondary education increased; at the same time, the dropout rate fell for primary education but increased for lower secondary education.

There is a study from the Banco Central de Bolivia with data available until 2011 indicating that enrollment, permanency and completion rates did increase in correlation with the Bono Juancito Pinto (Aguilar Pacajes 2014). Unfortunately, no data for superior education are provided.

McGuire (2013) explained that is not easy to make a clear assessment for lack of data, but confirmed that results for Bono Juancito Pinto are poor and for Bono Juana Azurduy should be better.

Attempting to explain the factors that drove inequality down, Vargas and Garriga (2015) found that the bonos played a smaller role, though the Renta Dignidad was surely efficient in its scope. The main part has been played by the reduction of skills premium for education (possibly due to strong increase in people with university education $)^{7}$, and the rise of wages for low skilled workers. As reported by Farthing and Kohl (2014), minimum wages rose by $60 \%$ in real terms between 2006 and 2013. The regions with higher labor income are Beni, Tarija, Santa Cruz, and Pando. According to these authors, the sectors where inequality and

\footnotetext{
${ }^{7}$ According to the Bolivian National Statistics Institute, in 2005 5,628 persons finished a State university course, while in 2014 the figure was 22,732 . For private education, the figures are 4,928 for 2005 and 8,174 for 2014.
} 
poverty decreased the most are the ones with people employed in services and manufacturing, while the decline was lower in the agricultural and mining sectors.

The Agrarian Reform

We shall now have a closer look at the efforts made to redistribute lands according to Law № 3545 explained in Section 1. At present, $72.5 \%$ of rural lands have legal certainty. This percentage is equivalent to 77 million of hectares, of which 67.7 have been secured under Morales administrations (Anuario INRA 2015). As Figure 1 shows, 33\% are State property, 31\% are TCO (belonging to original communities), $26 \%$ are owned by peasants and $10 \%$ by firms.

\section{FIGURE 1: STRUCTURE OF LAND} OWNERSHIP BOLIVIA, 2015

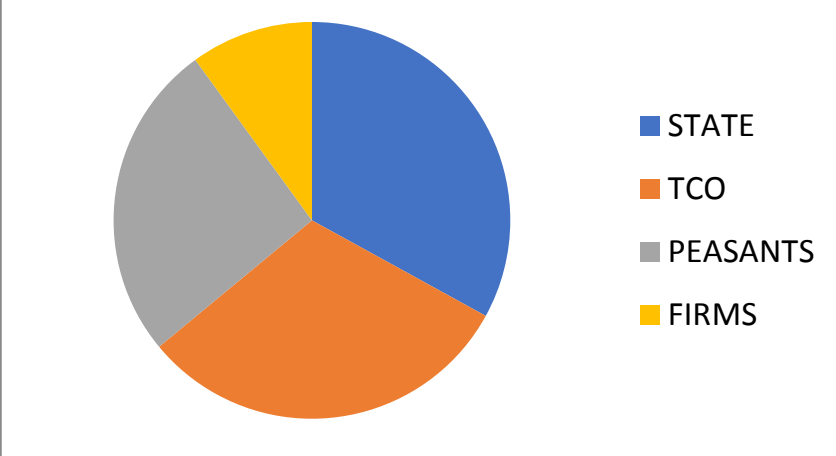

Source: INRA (2015)

This means that according to official sources, lands have been redistributed to indigenous groups, given the high percentage of TCO classification. This situation has changed greatly since the $1990 \mathrm{~s}$, when firms owned almost 2/3 of lands, as Figure 2 shows. 


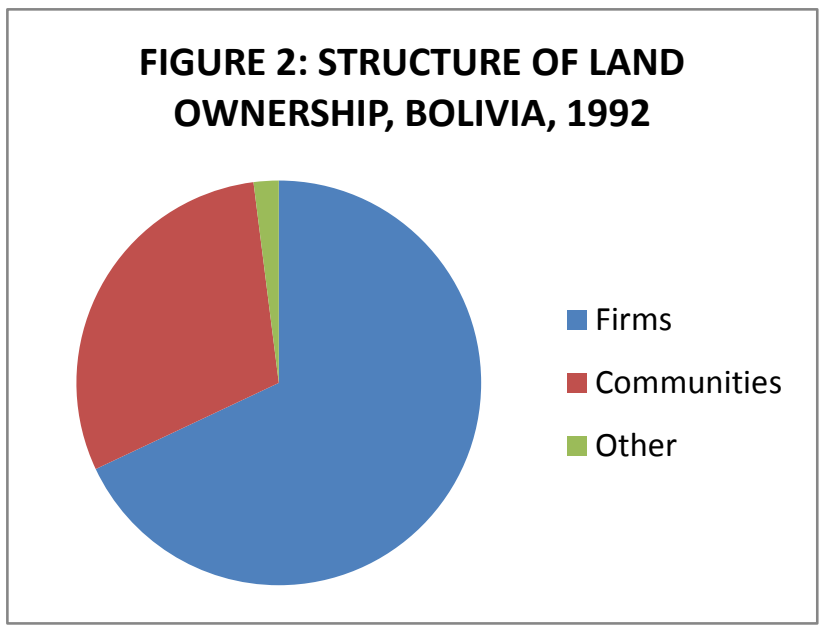

Source: INRA (2015)

The picture provided by Webber (2017) is far less enthusiastic.

\begin{tabular}{|l|c|c|c|}
\hline \multicolumn{2}{|c|}{$\begin{array}{c}\text { Number of } \\
\text { titles }\end{array}$} & $\begin{array}{c}\text { Surface area } \\
\text { (hectares) }\end{array}$ & Percentage \\
\hline Total surface area titled & 288,982 & 16510,514 & 100 \\
\hline Small property & 280,102 & 2327,345 & 14.1 \\
\hline Medium property & 1,823 & 963,587 & 5.8 \\
\hline Agricultural enterprise & 356 & 1339,972 & 8.1 \\
\hline Communitarian property & 6,523 & 4500,315 & 27.3 \\
\hline Communitarian lands of & 178 & 7379,295 & 44.7 \\
\hline origin (TCOs) & & & \\
\hline
\end{tabular}

Table 3: Details on Land Titled During Morales Government (2010-2014) Source: Webber 2017 
Official figures show that almost two thirds of land titles attributed to private subjects between 2010 and 2014 have gone to indigenous groups represented in Table 4 by communitarian property and TCOs that possess $72 \%$ of the total land titled during these years. But in the most profitable area, Santa Cruz, indigenous people have gained only a very small percentage of lands through the Agrarian Reform under Morales. Santa Cruz is a region located in the east of the country mostly formed of lowlands. Its agricultural strength relies mainly on the cultivation of soy, a legume that accounts for $35.5 \%$ of total Bolivian agricultural production.

\begin{tabular}{|l|c|c|c|c|c|}
\hline $\begin{array}{l}\text { Type of } \\
\text { property }\end{array}$ & $\begin{array}{l}\text { Surface } \\
\text { area } \\
\text { titled } \\
\text { (hectares) }\end{array}$ & \multicolumn{3}{|l}{$\begin{array}{l}\text { Number of } \\
\text { titles }\end{array}$} & \multicolumn{2}{l|}{$\begin{array}{l}\text { Surface area } \\
\text { per title } \\
\text { (average } \\
\text { hectares) }\end{array}$} \\
\hline Total & 3666,349 & 100.0 & 21,238 & 100.0 & $5,307.6$ \\
\hline Small property & 618,350 & 16.9 & 17,593 & 82.9 & 67.4 \\
\hline $\begin{array}{l}\text { Medium } \\
\text { property }\end{array}$ & 544,743 & 14.9 & 1,672 & 7.9 & 325.8 \\
\hline $\begin{array}{l}\text { Agricultural } \\
\text { enterprise }\end{array}$ & 1711,014 & 46.7 & 888 & 4.2 & $1,926.8$ \\
\hline $\begin{array}{l}\text { Communitarian } \\
\text { property }\end{array}$ & 323,924 & 8.8 & 376 & 1.8 & 861.5 \\
\hline $\begin{array}{l}\text { Communitarian } \\
\text { lands of origin } \\
\text { (TCOs) }\end{array}$ & 138,899 & 3.8 & 87 & 0.4 & $1,596.5$ \\
\hline Unknown & 329,419 & 9.0 & 622 & 2.9 & 529.6 \\
\hline
\end{tabular}

Table 4: Details on Land Titled During Morales Government in Santa Cruz (2010-2014) Source: Webber 2017

Santa Cruz is responsible for $76.3 \%$ of total Bolivian agricultural production. The agrarian reform allocated almost half $(46.7 \%)$ of the newly titled land to agricultural enterprise, meaning national and foreign capital. Communitarian property plus TCOs account only for $12.6 \%$ of titled land in 
Santa Cruz. Webber suggests that the peasants who gained small properties are rich and integrated into the State, but many are still landless despite the reform.

Therefore, we can conclude that although a quantitative analysis would maintain that there has been a strong redistribution to indigenous groups, a qualitative analysis reveals that land redistribution has actually favored the country's rich and powerful groups more than the indigenous and poor ones.

\section{Characteristics of the Bolivian Economy}

\subsection{The Crucial Importance of Gas Exports}

We can check data on how important natural gas exports are in order to finance public expenditures, as we understood earlier.

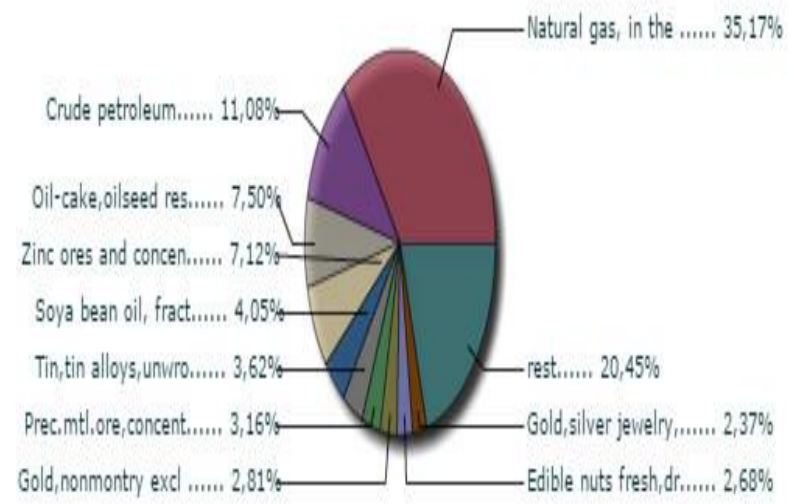

Figure 3: Composition of Exports to the Rest of the World Bolivia, 2005

Source: ECLAC Database 


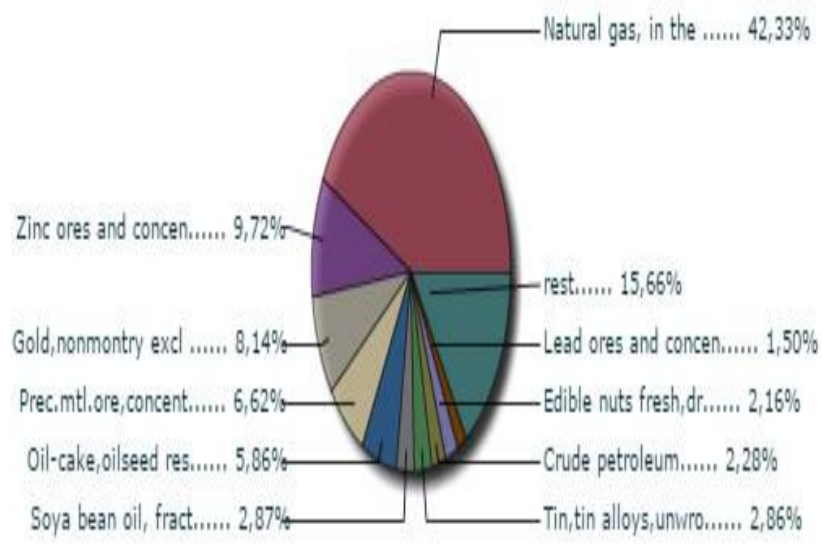

Figure 4: Composition of Exports to the Rest of the World Bolivia, 2015

Source: ECLAC Database

Figures 3 and 4 show that there has been an important increase in the volume of natural gas exported in the gaseous state between 2005 and 2015, passing from $35.17 \%$ to $42.33 \%$. Crude petroleum lost a consistent share (from $11.08 \%$ to $2.28 \%$ ). Gold exports increased too (from $2.81 \%$ to $8.14 \%$ ), but this and other mineral commodities are far less relevant to the Bolivian commercial balance, even though the first axis of the New Bolivian Model includes them. These developments are coherent with the contributions extractive sectors made in the last decade.

In Figure 5, we can see that the extractive sector passed from being the fifth contributor to GDP in 2006 to being the first one (excluding taxes) in 2014. In 2015 a declinehas lowered this share to almost the 2005 level. These developments mirror the evolution in natural gas prices, as we shall see. Coherent with the strong role assumed by the State, the public share rose until becoming the main contributor to GDP in 2015. At the same time, the manufacturing sector progressively lost share from 2009 until 2014, and improved only in 2015; still, it is one of Bolivia's strongest contributors to growth. When looking at these data, one should remember that in 2014 and 2015 GDP growth decelerated. (Source: World Bank) 


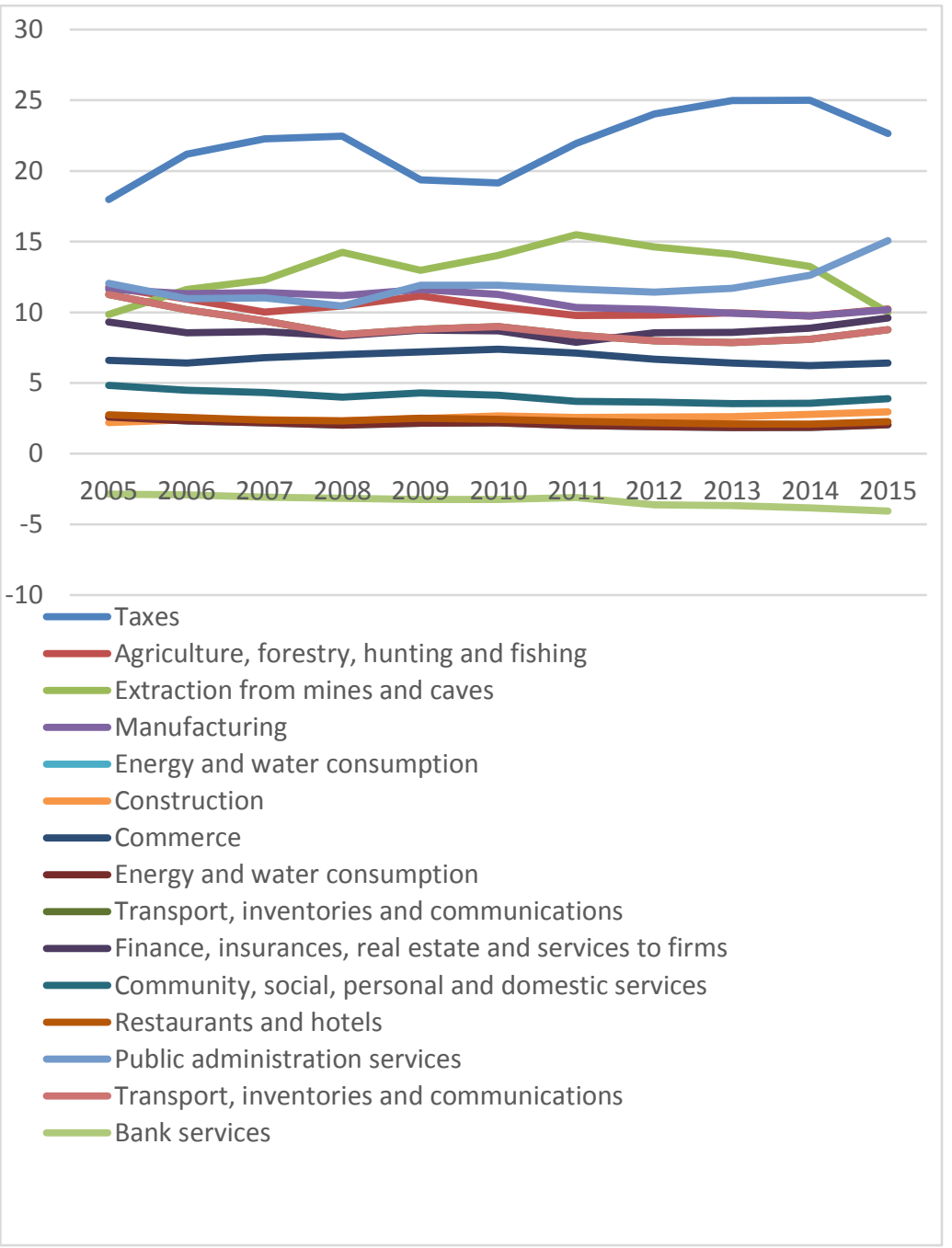

Figure 5: Contribution to GDP at Market Prices for Economic Activity (\% of GDP) Bolivia, 2005-2015

Source: Bolivian National Statistics Institute 
The question arises whether Bolivia will be able to maintain its current gains in natural gas exports in order to finance its economic development and its social spending.

According to a study by Chávez-Rodríguez et al., (2016) based on World Bank data at least until 2030 the volumes of gas sold to Argentina and Brazil (currently the only foreign buyers of Bolivian natural gas) should keep growing. The domestic market should also increase by $6.6 \%$ due to subsidized consumption and the development of a fertilizer industry that will use gas, decreasing dependence on the export of primary products. There is a possibility that Argentina will reduce its purchases because of the exploitation of shale gas, but it seems unlikely that the country will stop Bolivia's exports before 2027 given contractual commitments. This study also explains that, according to current Bolivian legislation, natural gas extraction has to satisfy domestic needs first. While its authors see this from a critical viewpoint, the projections they present about growing domestic gas consumption would confirm that the government is actually moving towards reinforcing the internal market as promised by Arce Catacora (2016, refer to Table 2).

We should also stress that, thanks to the contracts signed with companies that deliver gas to Argentina and Brazil, the price is set not according to the international price but to the evolving prices of three petroleum commodities (in contracts with Argentina they are four), depending on their performances in the previous semester (Fundación Jubileo 2016a). In this way, Bolivia manages to sell its gas at higher than international prices.

In Figure 6, we see how the natural gas price to Argentina and Brazil followed the oil price, usually with a bias of approximately one trimester. Comparing Figures 6 and 7 we can see that since 2007, only in the second semester of 2008 has the international price of gas (here represented by the Henry Hub index) been higher than the Bolivian gas; for the rest of the period, the latter has been higher, with the difference being particularly high between 2011 and 2014. These developments explain why the bonanza in Bolivia has been particularly strong: the country managed to sell its main commodity at a particularly favorable price. In 2015 and 2016, the Bolivian price decreased strongly because of the lower international oil price given the existing contracts (Fig. 6). Such a movement mirrors the decline of the contribution to Bolivian GDP from the extractive sector (Fig. 5). 


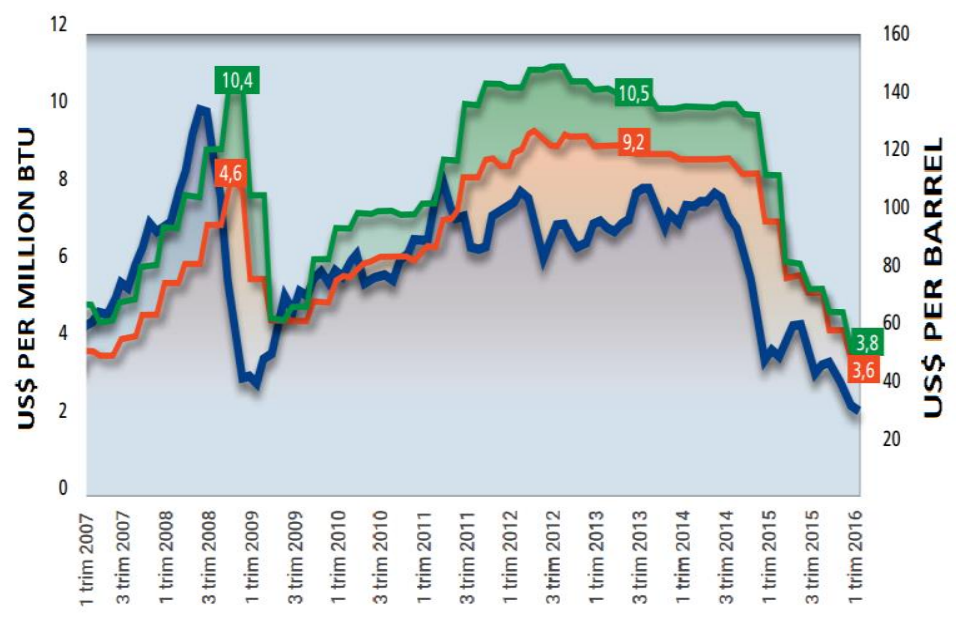

\section{— Export price to Brazil _ Export price to Argentina _ WTI Petroleum price}

Figure 6: Price of Bolivian Gas Sold to Argentina and Brazil, 2006-2016 Source: Fundación Jubileo 2016a

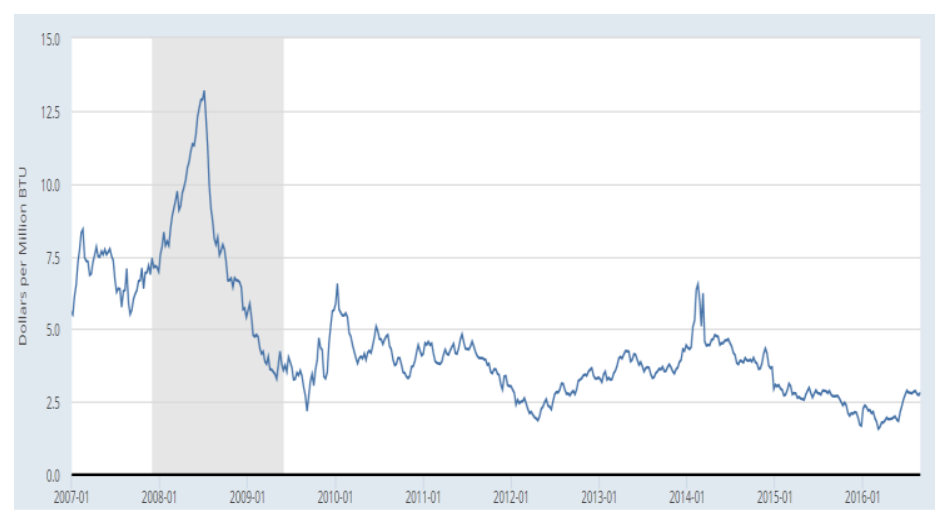

Figure 7: Price of Henry Hub Natural Gas Price, 2007-2016

Source: Federal Reserve Bank of Saint Louis

\footnotetext{
${ }^{8}$ This is the indicator of natural gas price most used internationally.
} 
Having understood how Bolivian gas contracts work, we can see that for Bolivia to keep good revenues from gas, we should check the forecasts for oil prices. In this sense, the US Energy Information Administration predicts a rise in the WTI price, but without reaching $\$ 100$ per barrel (as it was in 2014) before 2037 (Fig. 11). If these predictions prove correct, the Bolivian State will have to change its plans accordingly, without having a commodity boom at its disposal.

\section{AEO2017: Real Petroleum Prices: Crude Oil: West Texas Intermediate Spot}

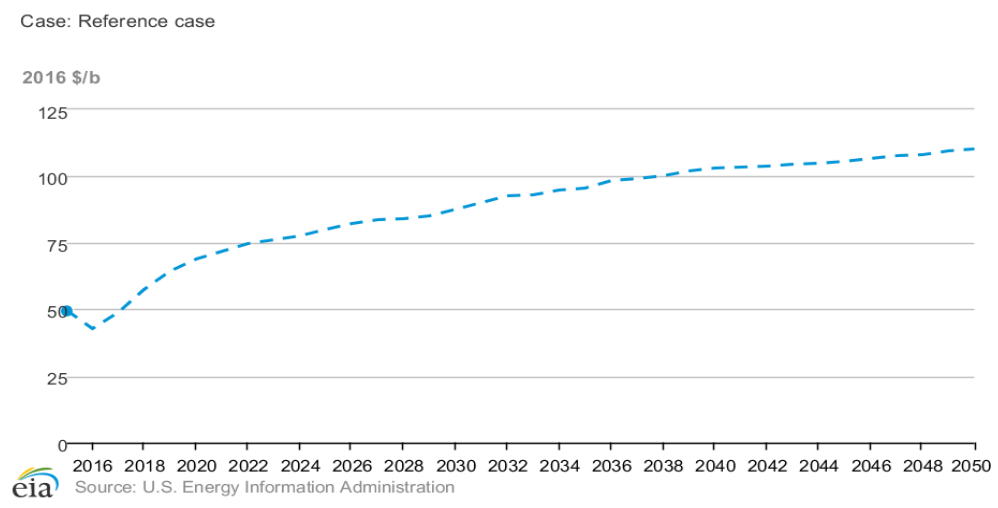

Figure 8: Projections for WTI Prices until 2050

Source: U.S. Energy Information Administration

\subsection{Industrialization of Bolivia}

There is literature (see for instance Mendes Loureiro 2016; Ettlinger and Hartmann 2016; Mun 2015) ${ }^{9}$ that considers this kind of neo-extractivist model unsustainable in the long term because it relies too much on profits over trade of raw materials to finance social programs and sustain macroeconomic stability. A crisis in the international price of raw materials would also trigger a crisis in the economy of these countries, as is happening in Venezuela.

\footnotetext{
9 Thanks to Rex McKenzie, Professor of Economics at Kingston University London, for the provision of Mendes Loureiro's paper.
} 
In light of these considerations, we should also ask ourselves whether Bolivia is moving or not towards reducing its dependence over the exports of primary products.

As accounted by Farthing and Kohl (2014), the government has focused its investments on infrastructures, which of course were, and still are, needed. Some industrial efforts have involved telecommunications (with the nationalization of previously privatized ENTEL), airlines (with the foundation of a new state company, Boliviana de Aviación (BOA) and the creation of a Development Bank to concede loans (Banco de Desarollo Productivo). Other investments, such as the one to industrialize the Mutún iron deposit to produce steel, were not successful, but are still planned.

\section{Overview of Bolivian Public Firms}

Overall, the number and the quality of projects started by the government to industrialize the country is impressive, as we saw in Table 1. But as we already noted, not all of them are fully working. Table 5 shows which ones are actually operating and which are not. We will use the distinction made by Arce Catacora (2016) among started, operating and consolidating projects. The first group includes firms just implemented, the second one firms with an already advanced stage of production and the third firms operating at high capacity.

\begin{tabular}{|l|l|l|}
\hline \multicolumn{4}{|l|}{ STARTED PROJECTS } \\
\hline AZUCARBOL & EASBA & EBIH \\
\hline ECEBOL & ENABOL & \multicolumn{1}{l|}{ PAPELBOL } \\
\hline MUTÚN & EEPS & \multicolumn{2}{l|}{ PROMIEL } \\
\hline EEPAF & BOLTUR & ENAVI \\
\hline OPERATING PROJECTS & \\
\hline CARTONBOL & COFADENA & EBA \\
\hline EMAPA & LACTEOSBOL & ABE \\
\hline Bolivia TV & ENDE & QUIPUS \\
\hline
\end{tabular}




\begin{tabular}{|l|l|l|}
\hline \multicolumn{3}{|l|}{ CONSOLIDA TING PROJECTS } \\
\hline BOA & DAB & TAB \\
\hline YPFB & COMIBOL & VINTO \\
\hline MI TELEFERICO & ENTEL & \\
\hline
\end{tabular}

Table 5: Bolivian Public Firms by Stage of Operations

Source: Arce Catacora 2016

If we compare this Table to Table 1, we discover that only firms from the first axis, the one dedicated to generate surplus, are in an advanced stage of production. Out of the 15 firms of the second axis, meant to foster private initiative, none is in an advanced stage and only six are even operating. This is an important point to underline. The firms of the second axis have the potential to impulse a strong evolution in Bolivian production, but at this moment their potential is still low. One of these, Azucarbol, was shut down because of lack of raw material in the chosen area (Quintanilla 2016). One of the firms of the third axis, Enabol, was shut down for bad administration ("Ferreira anuncia la disolución de Enabol." Los Tiempos digital, 27 July 2017). In the 2006-2016 period, public firms have hired 120,793 people (Ministerio de Economía y Finanzas Públicas, MEFP 2016).

We shall now make a deeper analysis of the performance of the most important of these firms to understand if the model is really working

\section{Hydrocarbons: YPFB}

The most important public firm is actually Yacimientos Petroliferos Fiscales Bolivianos (YPFB), the national enterprise that exploits oil and gas fields in Bolivian territory. It was "nationalized" on May 1, 2006, but this actually meant just a shift in tax arrangements since the firm was already a public firm nominally. YPFB is the most important source of revenue for the country. Production and profits have increased enormously in recent years. (Arce Catacora 2016) 


\begin{tabular}{|l|l|l|}
\hline & 2005 & 2014 \\
\hline $\begin{array}{l}\text { Production (in } \\
\text { MMm3/DAY) }\end{array}$ & 40,2 & 61,3 \\
\hline $\begin{array}{l}\text { Investment in } \\
\text { hydrocarbons (in } \\
\text { millions of dollars) }\end{array}$ & 246 & 2.111 \\
\hline $\begin{array}{l}\text { Internal consumption } \\
\text { (in hundreds of } \\
\text { MMpc) }\end{array}$ & 48 & 114 \\
\hline $\begin{array}{l}\text { Exports to Brazil and } \\
\text { Argentina (in } \\
\text { hundreds of MMpc) }\end{array}$ & 10,4 & 17,6 \\
\hline $\begin{array}{l}\text { State's rent from } \\
\text { hydrocarbon industry } \\
\text { (in millions of dollars) }\end{array}$ & 974 & 6.096 \\
\hline
\end{tabular}

Table 6: YPFB Developments (2005-2014)

Source: Arce Catacora 2016

\begin{tabular}{|l|l|l|}
\hline & 2001-2005 & 2006-2014 \\
\hline $\begin{array}{l}\text { YPFB profits (in } \\
\text { millions of dollars) }\end{array}$ & 644 & 7.908 \\
\hline
\end{tabular}

Table 7: YPFB Profits (2001-2014)

Source: Arce Catacora 2016

Judging from these figures, the hydrocarbons sector has fully respected government promises to foster production, internal consumption and revenue from exports. Profits coming from YPFB have also been largely used to finance the social programs reviewed in Section 2. Almost 2 million dollars went to the "new" welfare in 2014 from this source, according to Arce Catacora (2016). Its profits represented more than $90 \%$ of total public firm revenues in the boom ears, but this percentage dropped in the last two years given the fall of oil's international price. (MEFP 2016) 
Concerns, however, have been raised about:

- The rationality of YPFB organization as well as its transparency, due to a lack of complete information on its activities (Fundación Jubileo 2017)

- Lack of significant discoveries of new gas fields in the Morales era, with the exception of the Incahuasi field (Fundación Jubileo 2016b)

- Evolution of the price of oil (Fundación Jubileo 2016b), issue that we explored in the previous section.

\section{The Mining Sector: COMIBOL, Vinto, Mutún, Lithium}

Mining was traditionally a crucial industrial sector for the country, but since the 80 s, the relevance of $\mathrm{COMIBOL}$, the national mining company, had progressively decayed due to privatizations and to the international fall in the price of tin. With the Morales government, COMIBOL acquired new importance, also thanks to the nationalization of former private mines like the Huanuni one that provides tin and the Vinto smelter that processes the same material. Also in this sector, the picture is one of an economic boom that greatly benefited the Bolivian State. But as Arze Vargas (2017) notes, public and private investment in mining has been very scarce when compared to other Latin countries, amounting only to $3.6 \%$ and $4.9 \%$ of what has been invested in Chile and Peru, respectively.

\begin{tabular}{|l|c|c|}
\hline & 2005 & 2014 \\
\hline Index of minery production (1990=100) & 134 & 287 \\
\hline Mining exports (in tons of materials) & 474 & 1423 \\
\hline Mining exports (in millions of dollars) & 351 & 2,035 \\
\hline $\begin{array}{l}\text { State's rent from mining industry } \\
\text { (in millions of dollars) }\end{array}$ & 36,62 & 238,67 \\
\hline
\end{tabular}

Table 8: Evolution of Bolivia Minery (2005-2014)

Source: Data elaborated from Arce Catacora 2016 
According to Díaz Cuellar (2017), the rise in production is due mainly to transnational capital invested in the country before the Morales governments. Three mines controlled by foreign investment--San Cristóbal, San Bartolomé and San Vicente--are the most profitable. Transnational companies controlled $52 \%$ of mineral exports between 2006 and 2012. The State's revenue has also been very low in comparison with other periods of Bolivian history, though a little superior than the neoliberal era (1986-2005). The Chilean State controls a greater share of mineral production with its own firm and earns more from its privatized mines than Bolivia, according to the calculations of the author. Nevertheless, Vinto contributed with some millions of pesos to finance the subsidy for childhood education, the Bono Juancito Pinto (Empresa Metalúrgica Vinto, "Aporte a las Políticas Públicas").

A major mining project is Mutún. Located in Santa Cruz, it is one of the world's biggest iron sources (Farthing and Kohl 2014). It could be useful to produce steel and high-value added products. Still, the project has not yet taken off. A partnership had been established between the state-owned company Empresa Siderúrgica del Mutún (Mutún Steel Mill Firm) and the Indian Jindal Steel, but it was dropped in 2012 due to reciprocal legal accusations (Farthing and Kohl 2014). A new contract with the Chinese firm Sinosteel, has been signed and by 2020, the country should begin to export laminates (“Bolivia y China firman contrato..." La Razón, 21 Dec. 2017).

Another important project that is not taking off is the industrialization of lithium. According to Poveda (2018), Bolivia has the world's biggest lithium resource ( $27 \%$ of global resources). The most important one is located in Uyuni in the Oruro region. In a scenario where global demand for this mineral is estimated to rise, its industrialization with the aim of producing batteries would be crucial for the country's economic model. Regrettably, despite some governmental initiatives, this is not happening. By 2017, efforts proved completely unsatisfactory, according to the author.

In 2018, a new agreement with German firm ACl Systems to develop this industry has been announced and by 2019, operations should be in place (“Bolivia to invest..." Reuters, 21 April 2018)

\section{Overview of Value Added Production}

As shown in in Figure 5, the manufacturing contribution to GDP did not go 
beyond its 2005 level in recent years. Still, as reported in Arce Catacora (2016), manufacturing growth is higher than it was during the 1985-2005 period and the main driver of these improvements has been the production of nonmetallic minerals. For the future, the government plans to maintain the three axes strategy with 52 industrialization projects in 13 sectors (Ministerio de Planificación 2015). One of these is a urea plant that started to export half of its production to Brazil in November 2017 ("Inician operaciones..." Los Tiempos digital, 29 Nov. 2017).

As of 2014 , the number of firms is 28,277 . This represents a $219.3 \%$ rise compared to 2005 when the number was 8,856 (Arce Catacora 2016). Still, according to the Fundación Milenio (2016), despite a vivid entrepreneurial spirit, these firms have low productivity and generate scarce value added. Following Hira (2007), we will assess efforts to change Bolivia's industrial production, checking the general situation of value added production in the country.

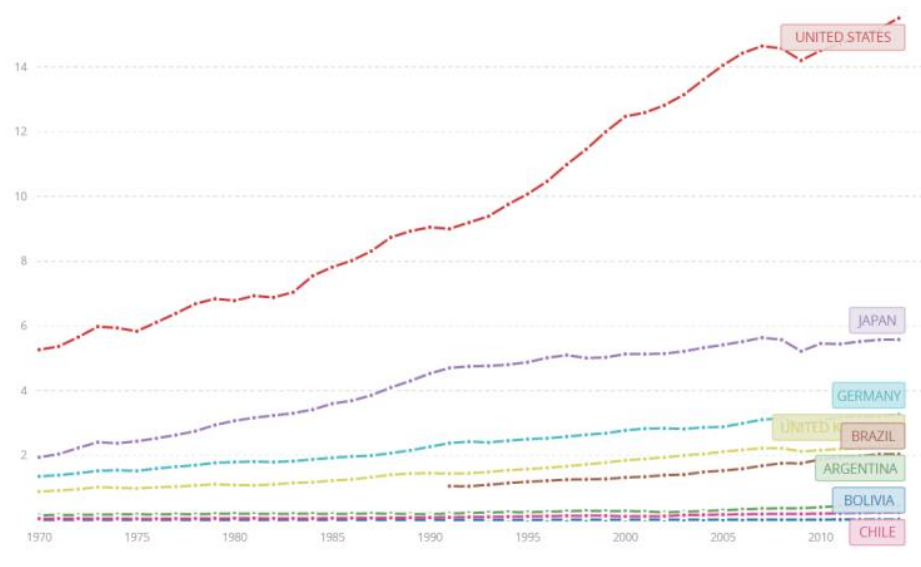

Figure 9: Gross Value added for Bolivia, United States, Japan, Germany, United Kingdom, Brazil, Argentina, Chile, 1970-2015 Source: World Bank

Gross value added has been growing constantly since 1992. Still, in Figure 9, one can see that the Gross Value Added has always been smaller than the other countries considered. While US, Japan, UK and Brazil produce trillions of dollars of value added, Bolivia, to date, has not even arrived at 20,000 billion 
of dollars. Catching up with main countries is a difficult if not impossible task in absolute terms. However, when looking only at Bolivia and the contribution of value added to GDP in each macro-sector, the last ten years have seen some improvements in respect to the past, which we may observe across sectors.

9

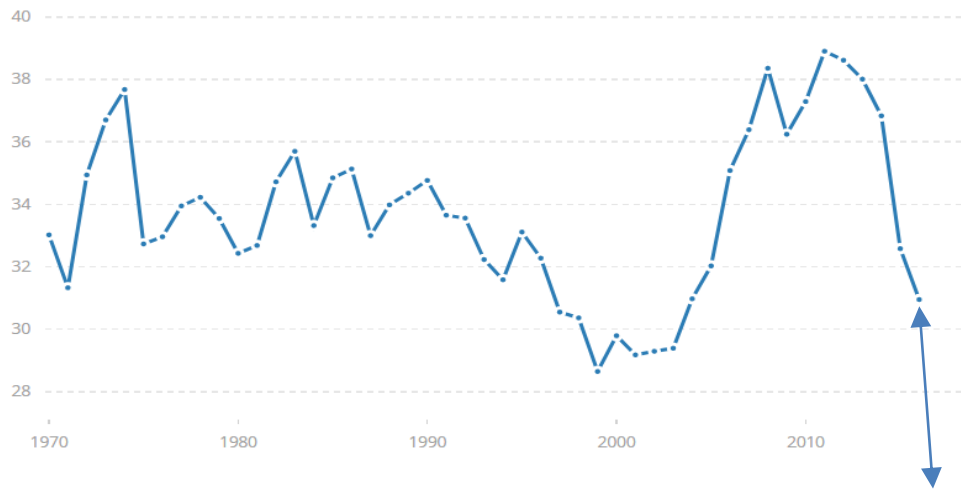

Figure 10: Industry, Value Added (\% of GDP)

Bolivia, 1970-2015

Source: World Bank

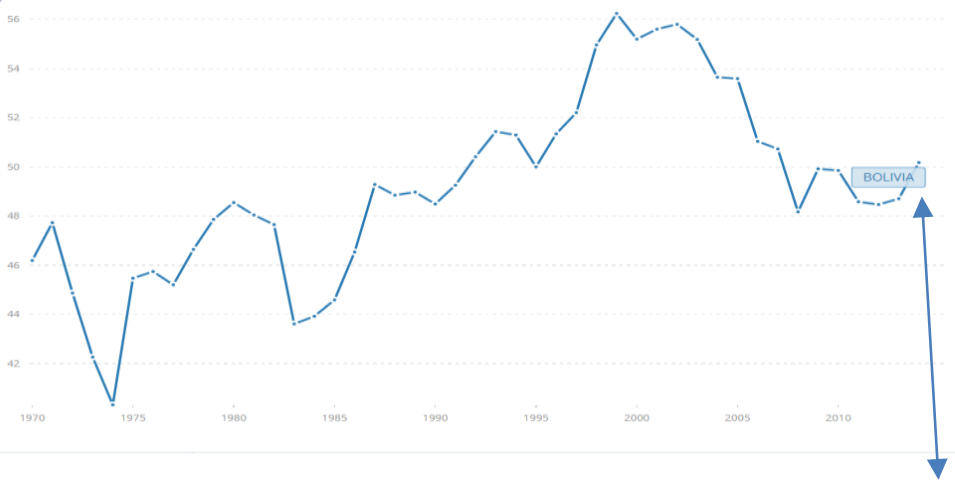

Figure 11: Services, Value Added (\% of GDP)

Bolivia, 1970-2016

Source: World Bank 


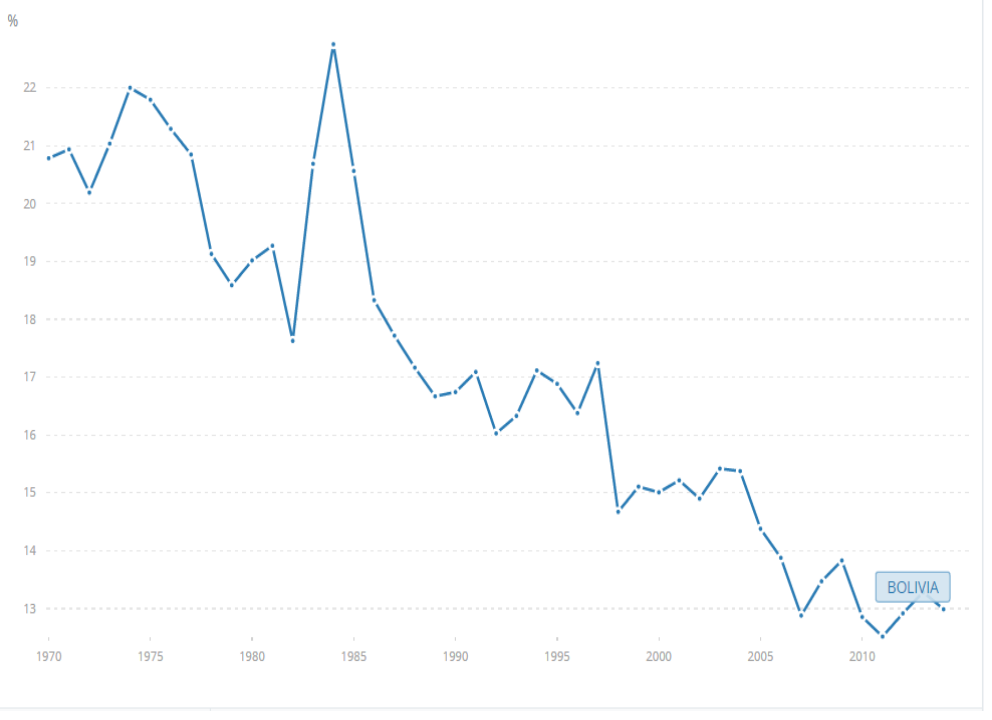

Figure 12: Agriculture, Value Added (\% of GDP)

Bolivia, 1970-2016

Source: World Bank

Figure 10 shows that value added in industry skyrocketed from 2003 to 2008, but there is a declining trend from 2011 to the present. Overall, we can say that there has been a strong increase in value added since Morales took office, something that goes hand in hand with the boom in natural gas and consequently in exports; a success story that now risks being inverted. Different is the value added relative to GDP for the services sector (Fig. 11), where the declining trend from the 90s has halted since 2008 and is now experiencing an increase for the agricultural sector (Fig. 12), where the declining trend that started in the 80 s is continuing even now.

Continuing to look at the contribution to GDP of value added, in Figure 13 we can see that this is higher in Bolivia than in many other countries in some sectors. As in Figure 12, I am comparing Bolivia with main developed countries in Latin America and in the world, depending on available data. 


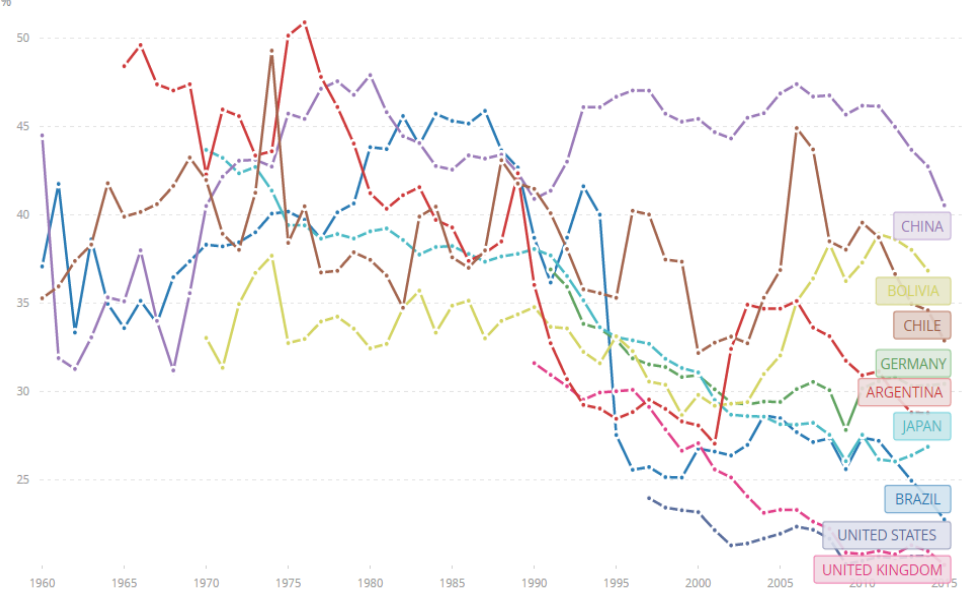

Figure 13: Industry, Value Added (\% of GDP), Argentina, Brazil, Bolivia, China, Chile, Germany, Japan, United Kingdom, United States, 1960-2015

Source: World Bank

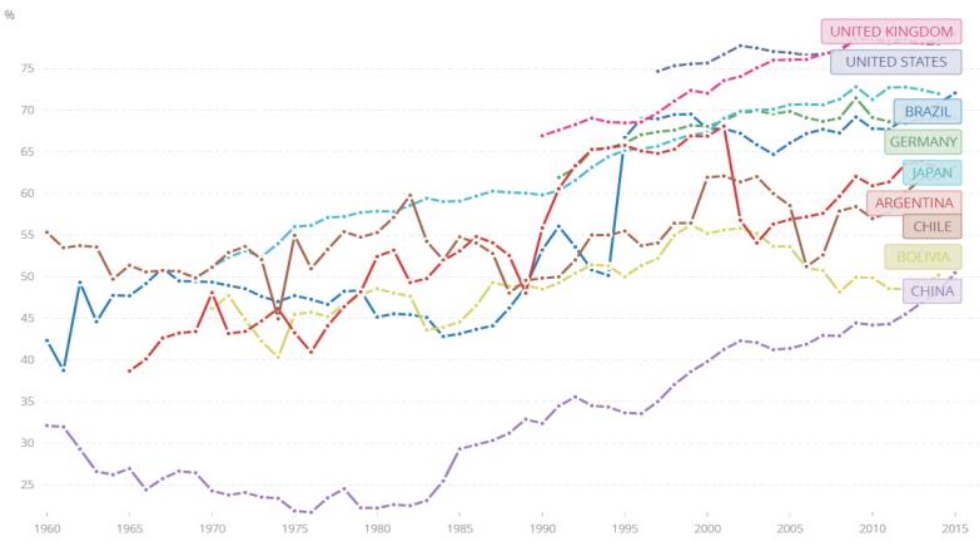

Figure 14: Services, Value Added (\% of GDP), Argentina, Brazil, Bolivia, China, Chile, Germany, Japan, United Kingdom, United States, 1960-2015 Source: World Bank 


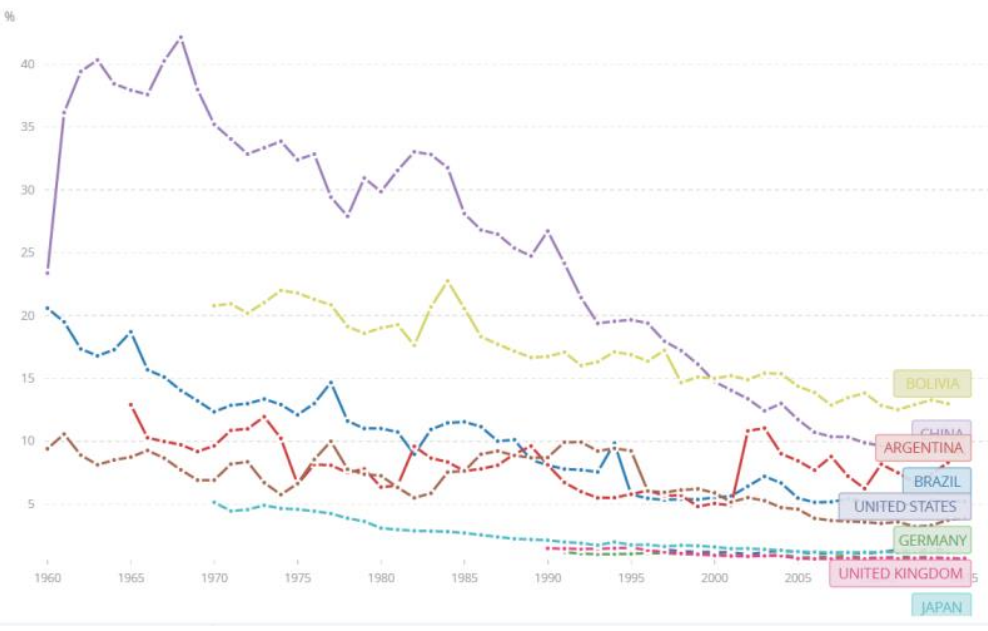

Figure 15: Agriculture, Value Added (\% of GDP), Argentina, Brazil, Bolivia, China, Chile, Germany, Japan, United Kingdom, United States, 1960-2015

Source: World Bank

In the foregoing tables, we see that for value added in industry (Fig. 13), Bolivia today has the second highest contribution to GDP within the chosen countries, while it was fifth in the $80 \mathrm{~s}$. In the field of services (Fig. 14), Bolivia is penultimate and in the field of agriculture (Fig. 15), despite the strong decline experienced since the $80 \mathrm{~s}$, it is the country with most value added to GDP among the others presented here, even with a stagnant trend. This means that in relative terms Bolivia is actually doing well in industrial and agricultural sectors with respect to other countries, given its smaller economy.

\section{Environmental Problems}

Concerns have been raised about the environmental sustainability of Bolivia's industrialization.

Morales-Hidalgo, Oswalt and Somathan (2015) report that protected areas have remained the same during the period we are analyzing. In 2000, the amount of hectares was 10,680 and it is still so in 2015 . The percentage of 
forests inside them is also about the same: $21.2 \%$ in 2000 and $22 \%$ in 2015 . Still, primary forest area in the country diminished in recent years.

\begin{tabular}{lllll}
\hline 1990 & 2000 & 2005 & 2010 & 2015 \\
\hline 40,804 & 39,046 & 38,164 & 37,164 & 36,164 \\
\hline
\end{tabular}

Table 9: Hectares of Primary Forest in Bolivia, 1990-2015

Source: Morales-Hidalgo, Oswalt and Somathan 2015

Forests decreased from 40,804 hectares in 1990 to 3,164 in 2015 (-11.4\%). In the period of the Morales presidency, the amount went from 38,164 (2005) to 36164 (2015), a decrease of $5.5 \%$.

Other concerns are the pollution of water caused by mining activity, an issue that became prominent during the recent and severe drought all over the nation. Campanini (2017) clarifies that the drought was not caused directly by mines. However, water is under serious risk of contamination by materials coming from extraction. At least $1 / 4$ of watersheds are in lands where companies have mining rights (Campanini and Gandarillas 2017). Despite the recent mining law that requires authorization for companies to start their operations, this provision does not apply to rights conceded before the new law. Concern over this issue is particularly strong given that water flowing to La Paz is still under contamination from a closed mine named Milluni.

Finally, there is the case of the conflict over highway construction through the TIPNIS protected natural park. The matter is in discussion since 2011, when a first attempt to start works was blocked by popular resistance. In 2017 , the government permitted the construction again, encountering resistance again. Fears are that TIPNIS may suffer a loss of $64 \%$ of its current forests (Vargas Rios et al., 2012).

Achtenberg (2013) explains the whole geopolitical struggle behind the road. There are some indigenous communities whose businesses would benefit from the construction, and locals that would not. Beni meat producers would quickly ship their products to Santa Cruz and local elites could lose control of the meatpacking and slaughterhouse industry. At the same time, the highway connects with an important east-west route of the Regional Infrastructure of South America (IIRSA), a continental integration project led by Brazil. Finally, 
the Bolivian government claims that the current project will minimize environmental hazards.

\section{Conclusions}

There is little doubt that Bolivia has made impressive improvement in all economic areas. Historically one of the poorest countries in Latin America and the world, during the presidency of Evo Morales the country has had strong and inclusive growth. While more than half of the population was living in poverty, less than half is poor now. Critical remarks are due regarding the agrarian reform and environmental protection. Nevertheless, a less lucky era may now be starting.

As we have shown, positive developments are strictly related to the oil price boom of the 00s that in turn condition the contracts ruling the sales of Bolivian gas to Argentina and Brazil. Predictions about future oil price do not favor Bolivia: it will not get lower than now but neither will it boom as in the past.

Though efforts to diversify the Bolivian economy have been strong and visible, they may not be sufficient to keep growth at the pace that it has enjoyed until now: value added created by production is still unsatisfactory and some important projects such as the Mutún and lithium industrialization have still to take off. It should also be noted that despite strong propaganda about nationalizations, reliance on foreign investments remains high.

The economic model proposed by Morales and Arce Catacora is theoretically interesting because it proposes using public enterprises in such a dynamic way that they foster private initiative as well. In practice, however, the model still does not work properly due to the partial failure of this "second axis."

At the same time, it is unlikely that the country will experience a crisis similar to the one that Venezuela is having. The economy is still doing well and no major oil crisis is expected, at least based on current predictions. The hope is that efforts to stimulate public and private sector activities will be sufficient to keep getting people out of poverty. 


\section{Works Cited}

ACHTENBERG, Emily. 2013. "Contested Development: The Geopolitics of Bolivia's TIPNIS Conflict." Nacla Report on the Americas 46. 6-11. [https://nacla.org/article/contested-development-geopoliticsbolivia\%E2\%80\%99s-tipnis-conflict] downloaded February 2, 2018.

AGUILAR PACAJES, Hernán. 2014. "Evaluación del impacto del 'Bono Juancito Pinto' en Bolivia." Revista de Análisis 21. 37-66.

[https://www.bcb.gob.bo/webdocs/publicacionesbcb/2_Bono_Juancito_ Pinto.pdf] downloaded February 2, 2018.

ARCE CATACORA, Luis Alberto. 2016. El modelo económico, social, comunitario y productivo boliviano. La Paz: SOIPA Ltd.

ARTARAZ, Kepa and Calestani, Melania. 2014. "Suma qamaña in Bolivia: Indigenous Understandings of Well-being and their Contribution to a Post-Neoliberal Paradigm." Latin American Perspectives 42(5): 216-233.

ARZE VARGAS, Carlos. 2017. “¿Habrá inversión minera suficiente en Bolivia?” Reporte Anual de Industrias Extractivas. La Paz: Centro de Estudios para el Desarrollo Laboral y Agrario - CEDLA. 1-38.

CAMPANINI, Oscar. 2017. "Agua y minería en Bolivia: ¿Riesgos lejanos? El caso de la provisión de agua para consumo doméstico a la ciudad de La Paz." Deliberar. La Paz: Centro de Documentación e Información Bolivia CEDIB. 34-44. [https://www.cedib.org/wpcontent/uploads/2017/08/agua-y-mineria-en-Bolivia.pdf] downloaded February 11, 2018.

CAMPANINI, Oscar and Marco Gandarillas. 2017. "Minería y agua: supremacía extractivista y erosión de derechos." Elemento de vida: el agua en el desarollo, la cultura y la sociedad. La Paz: Cooperación Suiza en Bolivia. [https://www.kioscoverde.bo/wp-content/uploads/2017/12/RevistaAgua- 2016-2017- Coop-Suiza.pdf] downloaded February 11, 2018.

CHÁVEZ-RODRígUEZ, Mauro F. et al. 2016. “Can Bolivia Keep its Role as a Major Natural Gas Exporter in South America?" Journal of Natural Gas Science and Engineering 33. 717-730.

DÍAZ CUELLAR, Vladimir. 2017. "Ganancia, salario y renta en el sector minero en Bolivia durante el gobierno del MAS (2006-2015)." Reporte Anual de 
Industrias Extractivas. La Paz: Centro de Estudios para el Desarrollo Laboral y Agrario - CEDLA. 39-63.

EMPRESA METALÚRGICA VINTO. EMPRESA ESTRATÉGICA DEL ESTADO BOLIVIANO. "Aporte a las Políticas Públicas."

[http://www.vinto.gob.bo/?page_id=108] downloaded February 11, 2018.

ETTLINGER, Nancy and Christopher D. Hartmann. 2015. "Post/neo/liberalism in Relational Perspective." Political Geography 48. 37-48.

FARTHING, Linda C. and Benjamin H. Kohl. 2014. Evo's Bolivia: Continuity and Change. Austin: University of Texas Press.

FUNDACIÓN JUBILEO. 2016a. "Ante lenta recuperación del precio de hidrocarburos el país tiene el reto de diversificar ingresos." Revista Jubileo 33. 4-7. [http://www.jubileobolivia.org.bo/publicaciones/revistajubileo/item/download/344_b8389f3672eaaaa61ece96758eaf9fb1.html ] downloaded February 11, 2018.

---. 2016b. El sector hidrocarburos hoy. Serie Debate Público № 42. La Paz: Fundación Jubileo.

[file://C:/Users/CS_User/Downloads/Hidrocarburos_Hoy_Jun_16.pdf] downloaded February 11, 2018.

---. 2017. YPFB: Entre reestructuracciones y debilidad institucional. Boletín Electrónico de Industrias Extractivas. La Paz: Fundación Jubileo. [file:///C:/Users/CS_User/Downloads/Boletin_hidrocarburos_817_YPFB.pdf] downloaded February 11, 2018.

FUNDACIÓN MILENIO. 2016. ¿Como está Bolivia en emprendimiento e innovación? [https://fundacion-milenio.org/coy-322-esta-boliviaemprendimiento-e-innovacion/] downloaded February 11, 2018.

GACETA OFICIAL DE BOLIVIA. 2007. Plan Nacional de Desarrollo: "Bolivia Digna, Soberana, Productiva y Democrática para Vivir Bien." Lineamentos Estratégicos 2006-2011. La Paz-Bolivia. [http://www.ademaf.gob.bo/normas/ds29272.pdf] downloaded February 11, 2018.

---. 2009. Constitución Política del Estado. La Paz-Bolivia. [https://www.vicepresidencia.gob.bo/IMG/pdf/ncpe_cepd.pdf] downloaded February 11, 2018. 
GARCÍA LINERA, Álvaro. 2011. Las tensiones creativas de la revolución: la quinta fase del Proceso de Cambio. La Paz: Vicepresidencia del Estado, Presidencia de la Asamblea Legislativa Plurinacional.

HIRA, Anil. 2007. "Did ISI Fail and is Neoliberalism the Answer for Latin America? Re-assessing Common Wisdom Regarding Economic Policies in the Region." Brazilian Journal of Political Economy 27(3): 345-356.

KLEIN, Herbert S. (2011) A Concise History of Bolivia. Cambridge, U.K.: Cambridge University Press.

LA RAZÓN. 2017. "Bolivia y China firman contrato de crédito por \$us 420 MM para el proyecto del Mutún." [http://204.11.233.100/economia/Mutuncredito-firma-Bolivia-proyecto_0_2841915825.html] downloaded March 5, 2018.

LOS TIEMPOS. 2017. "Ferreira anuncia la disolución de Enabol." [http://www.lostiempos.com/actualidad/economia/20170727/ferreiraanuncia-disolucion-enabol] downloaded March 5, 2018.

---. 2017. "Inician operaciones de exportación de urea boliviana a Brasil." [http://www.lostiempos.com/actualidad/economia/20171129/inicianoperaciones-exportacion- urea-boliviana-brasil] downloaded March 5, 2018.

McNAY, Lois. 2009. "Self as Enterprise: Dilemmas of Control and Resistance in Foucault's The Birth of Biopolitics." Theory, Culture \& Society 26(6): 5577.

MEDINACELI MONRROY, Mauricio. 2012. The Colors of Hydrocarbons Nationalization in Bolivia.

[http://www.mmedinaceli.com/index.php?option=com_content\&view=a rticle\&id=50:blog030\&catid=3: contenblog\&ltemid=6\&lang=en] downloaded March 5, 2018.

MENDES LOUREIRO, Pedro. 2016. "Reformism, Class Conciliation and the Pink Tide: Prospects for the Working Classes Under Left-Of-Centre Governments in Latin America." Paper provided by ANPEC (Associação Nacional dos Centros de Pósgraduação em Economia) [Brazilian Association of Graduate Programs in Economics]. Anais do XLIII Encontro Nacional de Economia [Proceedings of the 43rd Brazilian Economics Meeting] 020.

[https://www.anpec.org.br/encontro/2015/submissao/files_l/i2158393abe0b1077b435ab7d622ccf067.pdf] downloaded March 5, 2018. 
MINISTERIO DE ECONOMÍA Y FINANZAS PÚBLICAS (MEFP). 2017. Las empresas públicas en el nuevo modelo económico boliviano. La PazBolivia.

MINISTERIO DE PLANIFICACIÓN DEL DESARROLLO. 2015. Plan de Desarrollo Económico y Social en el Marco del Desarollo Integral para Vivir Bien. La Paz-Bolivia. [http://www.boliviawdc.org/images/publicaciones/PND.pdf] downloaded March 5, 2018.

MORALES-HIDALGO, David, Sonja N. Oswalt, and E. Somanthan. 2015. "Status and Trends in Global Primary Forest, Protected Areas, and Areas Designated for Conservation of Biodiversity from the Global Forest Resources Assessment 2015." Forest Ecology and Management 352(7): 68-77.

MUN, Nam-Kwon. 2015. "La problemática transición boliviana hacia la época postneoliberal: el caso de la economía comunitaria." Revista de Estudios Sociales 54. 25-38.

OSTRY, Jonathan D, Prakash Loungani, and Davide Furceri Davide. 2016. “Neoliberalism: Oversold?” Finance \& Development 53(2): 38-41.

POVEDA ÁVILA, Pablo. 2018. "Cambios en la industria del litio y suspenso en su industrialización en Bolivia." Reporte Anual de Industrias Extractivas. La Paz: Centro de Estudios para el Desarrollo Laboral y Agrario - CEDLA. 137-172.

QUINTANILLA, Víctor. 2016. “El Gobierno cierra Azucarbol tras 4 años de desahuciar el Proyecto." Opinión (Cochabamba) 29 de octubre 2016. [http://www.opinion.com.bo/opinion/articulos/2016/1029/noticias.php ?id=203485] downloaded March 5, 2018.

REUTERS. 2018. "Bolivia to Invest in Billion-dollar Lithium Deal with $\mathrm{ACl}$ Systems." 21 April. [https://www.reuters.com/article/us-bolivialithium/bolivia-to-invest-in-billion-dollar-lithium-deal-with-aci-systemsidUSKBN1HSORW] downloaded March 5, 2018.

VARGAS, José P. Mauricio and Santiago Garriga. 2015. "Explaining Inequality and Poverty Reduction in Bolivia." IMF Working Papers 15(265): 1. [https://www.imf.org/ /media/Websites/IMF/imported-full-textpdf/external/pubs/ft/wp/2015/_wp15265.ashx] downloaded March 5, 2018.

VARGAS RÍOS, María Teresa, Noelia Garzón Rivero, Edil Osinaca Rico, and Robert Müller. 2012. Compensación por servicios ambientales de 
carbono: Una alternativa para reducir la deforestación en el TIPNIS. La Paz: PIEB.

WEBBER, Jeffery R. 2011a. Red October: Left-Indigenous Struggles in Modern Bolivia. Leiden and Boston: Brill.

---. 2011b. From Rebellion to Reform in Bolivia: Class Struggle, Indigenous Liberation and the Politics of Evo Morales. Chicago, IL.: Haymarket Books.

---. 2017. "Evo Morales, Transformismo, and the Consolidation of Agrarian Capitalism in Bolivia." Journal of Agrarian Change 17(2): 330-347.

WILLIAMSON, James. 1990. "What Washington Means by Policy Reform." In James Williamson, ed. Latin American Adjustment: How Much Has Happened? Washington, D.C.: Institute for International Economics. 7-20. [https://piie.com/commentary/speeches-papers/what-washingtonmeans-policy-reform] downloaded March 5, 2018. 